\title{
EDIACARAN SURVIVORS
}

CONWAY MORRIS, Simon, Dept. of Earth Sciences, University of Cambriage, Downing Street, Cambridge CB2 3EQ, U.K.

Ediacaran taxa are a characteristic element of latest Precambrian biotas, with an effectively global distribution. Their time range is not we 11 understood, but with one possible exception from western Canada Ediacaran faunas appear always to post-date the late Precambrian glaciations. There is also growing evidence that many Ediacaran taxa disappeared before the Precambrian-Cambrian boundary. These disappearances traditionally have been ascribed to changes in taphonomic circumstances, but a series of extinctions is a plausible alternative. Ediacaran fossils pose two major problems: Notwithstanding the reasons for their disappearance shortly before the Precambrian-Cambrian boundary, was their demise total or did some forms persist into the Cambrian? Second, is the traditional view that Ediacaran taxa are metazoans, many of a cnidarian grade, correct? Recently Seilacher, Bergström and others have argued that the Ediacaran organisms have a distinctive bauplan, difficult to reconcile with known phyla and possibly different from any metazoan.

In the Cambrian, Burgess Shale-type faunas are the principal source of information on soft-bodied metazoans. The differences between them and Ediacaran assemblages are largely self-evident, but there is now unequivocal evidence for at least one Ediacaran survivor from the Middle Cambrian Burgess Shale of British Columbia. This is a sea-pen-like animal, known from three specimens (one adult about $20 \mathrm{~cm}$ in length, and two juveniles). The fossils consist of a broad frond, with branches arising from a central axis on one side, while the opposite side is smooth apart from longitudinal ridges. The frond extends into a blunt holdfast that presumably was embedded in the muddy silt of the sea floor. This fossil is strikingly similar to the Ediacaran taxon Charniodiscus, best known from South Australia. The Burgess Shale example shows two important features. The first are pustule-like structures, possibly zooids, both on the branches and adjacent to the axis. The second feature is evidence for connections between the branches and axis, possibly representing canals. These features both support a comparison with extant pennatulaceans, and suggest that at least some Ediacaran taxa are correctly assigned to the metazoans.

Also occurring in the Burgess Shale is an enigmatic bag-like organism Mackenzia costalis. Clear evidence exists for it being benthic, but its mode of feeding is uncertain. The interior appears to have consisted largely of a spacious cavity, probably sub-divided by longitudinal partitions. In addition, an elongate strand may represent a discrete organ, perhaps connected with digestion or reproduction. No exact equivalent to Mackenzia appears to occur in Ediacaran assemblages, but bag-like taxa are a common component. These include erniettids, best known from Namibia, and Platypholina, from the White Sea region of Russia. 